\title{
Sensitivity of nested PCR toward human cytomegalovirus-DNA in native sera and in extracted DNA of serum samples
}

\author{
Sahar Shoman ${ }^{1}$, Ashraf Tabl ${ }^{2}$, Hussam Ghanem ${ }^{1}$, Mohamed Nabil ${ }^{1}$ \\ 1- Department of Microbiology, Faculty of Science, Ain Shams University, Cairo, Egypt. \\ 2- Department of Biomedical Technology, National Research Center, Giza, Egypt.
}

\begin{abstract}
PCR has been commonly used for genomic viral diagnosis for its sensitivity and accuracy. It showed a higher sensitivity when compared to virus isolation in tissue culture and also in antigenemia detection. Definitely, DNA samples are critical factor in PCR validity. Out of 84 serum samples subjected to this study and extracted by Wizard ${ }^{\circledR}$ DNA purification mini kit, 27 samples $(32.1 \%)$ were positive PCR. While, 15 samples (17.9\%) only out of the same population study (84) were positive PCR for HCMV DNA in native serum samples (without DNA extraction). This result was confirmed the importance of DNA extraction from serum samples for detection of HCMV which, subsequently lead to more sensitive diagnostic tool of an ongoing HCMV infection.
\end{abstract}

Keywords: HCMV DNA, HCV RNA, nested PCR, DNA extraction, serum.

\section{INTRODUCTION}

Human cytomegalovirus (HCMV) is known to cause mild or asymptomatic infection in most healthy individuals but it can also cause symptomatic disease in congenitally infected or premature neonates as well as in some immunosuppressed hosts (Abdolreza et al., 2010).

The most commonly used method to detect HCMV infections was, until recently, conventional cell culture on human fetal lung fibroblasts. The problem with this procedure is that cytopathic effect (CPE) evolves, most of the time, very slowly: it can take up to 21 days to visualize the CPE of HCMV infection in cultured cells (The et al., 1995).

Long time ago, HCMV was detected by centrifugation of leucocytes in a shell vial. Immediate early antigens were detected $48 \mathrm{hrs}$ later by using a monoclonal antibody, which recognizes the 72-kDa protein (Gleaves et al., 1984). Alternatively, it is possible to detect HCMV antigens, in blood, by using monoclonal antibody to the pp65 HCMV protein (The et al., 1995). The conventional technique, using dextran sedimentation, seems to be time consuming: 5 hrs is required to obtain a result. Today, methods based on the direct detection of either the viral genomic DNA or the viral mRNAs synthesized at different times of the viral replication cycle are more and more currently used.

Nucleic acid amplification by PCR methods has become the most widely used diagnostic tool for CMV infection (Caliendo et al., 2000).

The diagnostic value of HCMV DNAemia detected by PCR of leukocytes of immunosuppressed patients has been restricted by its low correlation to HCMV viremia (Hamprecht and Gerth, 1994) and HCMV disease (Weber et al., 1994). Recent, studies have accepted PCR for detection of HCMV DNA in plasma (Spector et al., 1992; Aspin et al., 1994) and serum of immunosuppressed patients (Patel et al., 1994; Yamamoto et al., 2001) as a good tool for this purpose.

During recent years PCR protocols were applied for detection of numerous 
human viral and non-viral pathogens (Aquino and Figueiredo1, 2001). The ability to demonstrate the presence of viruses in clinical samples with unprecedented sensitive assays has been the driving force for using PCR as a novel diagnostic procedure. Problems are encountered, however, if PCR is employed for the detection of viruses that establish lifelong latency in the host interrupted by episodes of recurrences (Liliane et al., 2001). Thus, during acute infection with human cytomegalovirus (HCMV), viral DNA is readily detected by PCR in peripheral blood mononuclear cells (PBMCs), biopsies, serum, urine and various other specimens (Rogers et al., 1990; Brytting et al., 1992), but positive results may be obtained during asymptomatic reactivations and in latently infected healthy individuals as well (Bevan et at., 1991). Therefore, without further laboratory and clinical data, positive PCR results are difficult to interpret. So, this study was aimed to determine the best clinical samples which give the maximum validity and sensitivity of applied technique (nested PCR).

\section{MATERIALS AND METHODS Study population:}

A total of 84 serum samples were used for monitoring HCMV. The samples were kindly supplied from clinical units of El Demerdash Hospital, Wadii El Neil hospital, and El Moqawelon Hospital, Cairo, Egypt. Fifty three of these samples were positive HCV RNA and 31 were negative HCV RNA. Both positive and negative $\mathrm{HCV}$-serum samples were screened, in this study, for HCMV DNA by nested PCR. DNA extraction:

HCMV DNA was extracted from $300 \mu 1$ serum sample using Wizard $\AA$ DNA purification mini kit, Promega (Madison, USA), $300 \mu \mathrm{l}$ serum was added to $900 \mu \mathrm{l}$ Cell Lysis Solution (included in Wizard ${ }^{\circledR}$ DNA purification mini kit, Promega) and mixed well. After incubation at $30{ }^{\circ} \mathrm{C}$ for $10 \mathrm{~min}$, the tubes were centrifuged at $11500 \mathrm{xg}$ for $20 \mathrm{Sec}$ at room temperature; the supernatant was removed without distributing the visible white pellet.

$300 \mu \mathrm{l}$ Nucleic lyses solution (included in Wizard® DNA purification mini kit, Promega) was added to the tube containing the white pellet, mix well, then incubated at $37{ }^{\circ} \mathrm{C}$. $1.5 \mu \mathrm{l}$ of RNase solution (included in the same kit) was added and the sample was mixed by inverting the tube 2-5 times. The mixture was incubated at $37{ }^{\circ} \mathrm{C}$ for $15 \mathrm{~min}$, and then cooled at room temperature. $100 \mu \mathrm{l}$ protein precipitation solution (included in the kit) was added and vortex for 10-20 min. After centrifugation at $11500 \mathrm{xg}$ for $3 \mathrm{~min}$ at room temperature, the supernatant was transferred to a clean $1.5 \mathrm{ml}$ microcentrifuge tube containing $300 \mu l$ isopropanol, the tube was mixed well, then centrifuged at $11500 \mathrm{xg}$ for 1 min. The DNA was visualized as a small white pellet. The supernatant was removed and one sample volume of $70 \%$ ethanol was added to the pellet, then the mixture was centrifuged at $11500 \mathrm{xg}$, and then the ethanol supernatant was removed. $100 \mu \mathrm{l}$ DNA dehydrating solution (included in kit components) was added and DNA was rehydrated by incubating at $65^{\circ} \mathrm{C}$ for $1 \mathrm{~h}$, DNA was left over night at room temp, and then stored at $-20{ }^{\circ} \mathrm{C}$ until use.

\section{Nested PCR:}

Nested PCR for serum samples to detect HCMV DNA was carried out according to methods of Nelson et al., (1997) and Jones et al., (2000). The reaction mixture of the qualitative PCR contained, in total volume of $25 \mu \mathrm{l}, 5 \mu \mathrm{l}$ $10 \mathrm{X}$ buffer $(75 \mathrm{mM}$ Tris- $\mathrm{HCl} \mathrm{pH} 8.0$, $\left.50 \mathrm{mM} \mathrm{KCl}, 15 \mathrm{mM} \mathrm{MgCl}_{2}\right), 0.5 \mu \mathrm{l}$ $50 \mathrm{mM}$ dNTP mix, $0.25 \mu \mathrm{l}$ of primers gB1: $5 \mu \mathrm{l}$ GAGGACAACGAA ATCCTGTTGGGCA $3 \mu \mathrm{l}$ and gB2: 5 GTCGACGGTGGAGATACTGC TGAGG $3 \mu \mathrm{l}$ (Bioneer, Atlantic Avenue, Alameda, USA), $5 \mu$ DNA solution 
(DNA template), $14.15 \mu \mathrm{l}$ distilled water, and $0.1 \mu \mathrm{l} 2 \mathrm{U}$ of Taq DNA polymerase (Bioneer, USA) were added.

The thermal cycling protocol was applied as follows: pre-denaturation at $94^{\circ} \mathrm{C}$ for $5 \mathrm{~min}$, followed by 35 cycles of $94^{\circ} \mathrm{C}$ for $30 \mathrm{sec}$, annealing at $57^{\circ} \mathrm{C}$ for 30 sec, Extension at $72{ }^{\circ} \mathrm{C}$ for $60 \mathrm{sec}$ and final extension at $72{ }^{\circ} \mathrm{C}$ for $4 \mathrm{~min}$. Two microliters of the $1^{\text {st }} \mathrm{PCR}$ product were used in a nested-PCR containing the same components as mentioned above, except for internal primers gBn1: $5 \mu \mathrm{l}$ ACCACCGCACTGAGGAATGTCAG $3 \mu \mathrm{l} \quad$ and $\quad \mathrm{gBn} 2: \quad 5 \mu 1$ TCAATCATGCGTTTG AAGAGGTA 3 $\mu \mathrm{l}$ (Bioneer, Atlantic Avenue, Alameda, USA), at the same thermal cycling protocol.

\section{PCR Amplification of serum samples without DNA extraction:}

$1 \mathrm{ml}$ of human serum sample was boiled at $95^{\circ} \mathrm{C}$ for $2 \mathrm{~min}$, centrifuged at $11500 \mathrm{xg}$ for $5 \mathrm{~min}$. $5 \mu \mathrm{l}$ of the supernatant was used as DNA template in the same nested PCR protocol that mentioned above.

\section{RESULTS}

\section{Detection of HCMV DNA by nested} PCR:

\section{a. In DNA extracted from serum sample:}

Results in Fig. 1 showed that 27 out of 84 tested samples gave positive HCMV-DNA using nested-PCR technique for DNA extracted from serum samples. Among those positive cases, 20 of them $(74.1 \%)$ were positive $\mathrm{HCV}$ RNA. The remaining 7 cases $(25.9 \%)$ were negative HCV-RNA (Table 1).

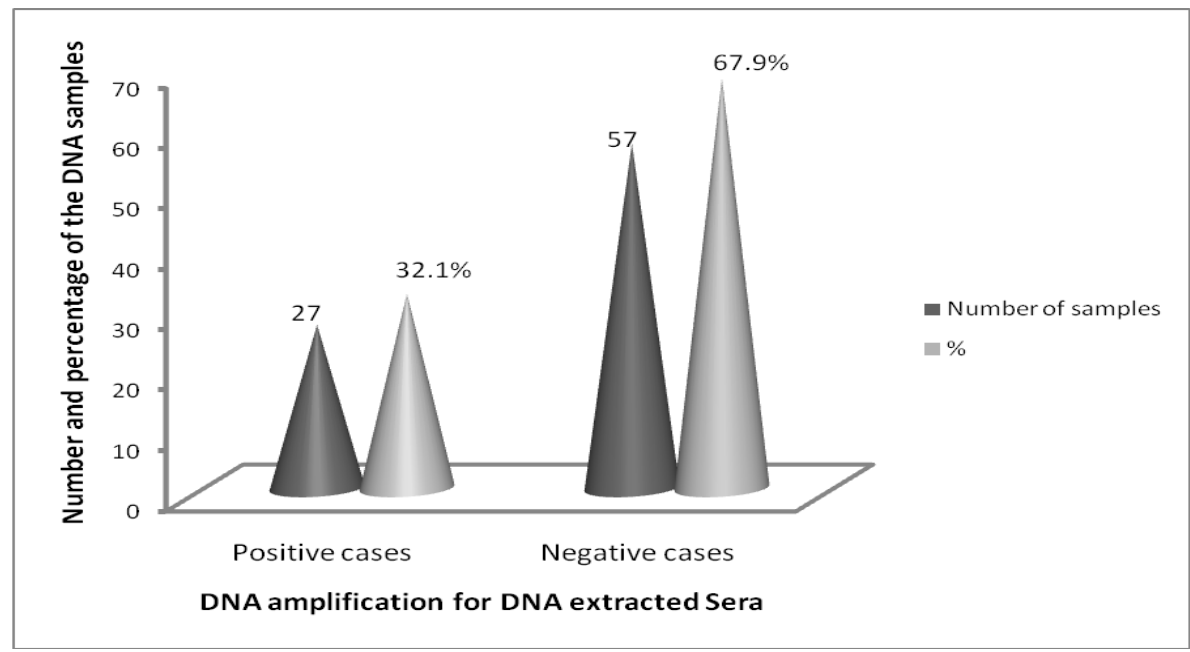

Fig. 1: Detection of HCMV-DNA from extracted DNA of serum samples using nested-PCR

Table 1: Detection of co-infection of HCMV and HCV in positive cases of HCMV infection.

\begin{tabular}{|c|c|c|}
\hline \multirow{2}{*}{$\begin{array}{c}\text { No. of positive } \\
\text { HCMV-DNA }\end{array}$} & \multicolumn{2}{|c|}{ Positive DNA amplification for DNA extracted sera } \\
\cline { 2 - 3 } & Positive HCV RNA & Negative HCV RNA \\
\hline 27 & $20(74.1 \%)$ & $7(25.9 \%)$ \\
\hline
\end{tabular}

\section{a. In native serum samples:}

Results in Fig.2 showed that the native serum samples (without extraction of HCMV-DNA) gave considerable reduction in the number of positive HCMV infection comparing with the previous cases (see Fig. 1). Where 15 out of 84 tested samples (17.8\%) were positive for HCMV-DNA. The majority of cases were negative for HCMV-DNA (Table 2). 


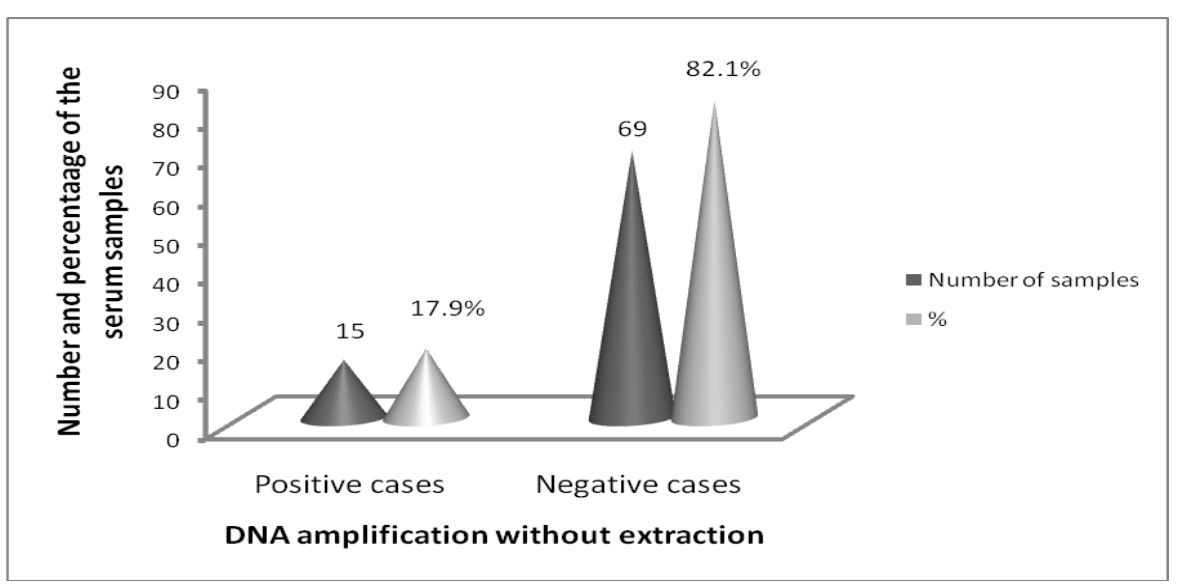

Fig. 2: Detection of HCMV-DNA in native serum samples using nested-PCR.

Table 2: Detection of co-infection of HCMV and HCV in Positive cases of HCMV infection.

\begin{tabular}{|c|c|c|}
\hline \multirow{2}{*}{$\begin{array}{c}\text { No. of positive } \\
\text { HCMV-DNA }\end{array}$} & \multicolumn{2}{|c|}{ Positive DNA amplification in native serum samples } \\
\cline { 2 - 3 } & Positive HCV RNA & Negative HCV RNA \\
\hline 15 & $12(80 \%)$ & $3(20 \%)$ \\
\hline
\end{tabular}

Nested-PCR indicated that all These results confirmed the necessity of tested positive HCMV-DNA samples extraction of viral genome (DNA) before were also positive (100\%) when DNA amplification by nested-PCR. Results in was extracted from serum samples. Fig.3 showed that the positive samples Whereas only 15/27 (55.6\%) were gave PCR-product at $100 \mathrm{bp}$ as an positive when native serum samples were expected size of HCMV-DNA fragment. used without DNA extraction (Table 3).

Table 3: Detection of HCMV DNA in some selected samples showing DNA amplification using either DNA extraction kit or native unprocessed sera.

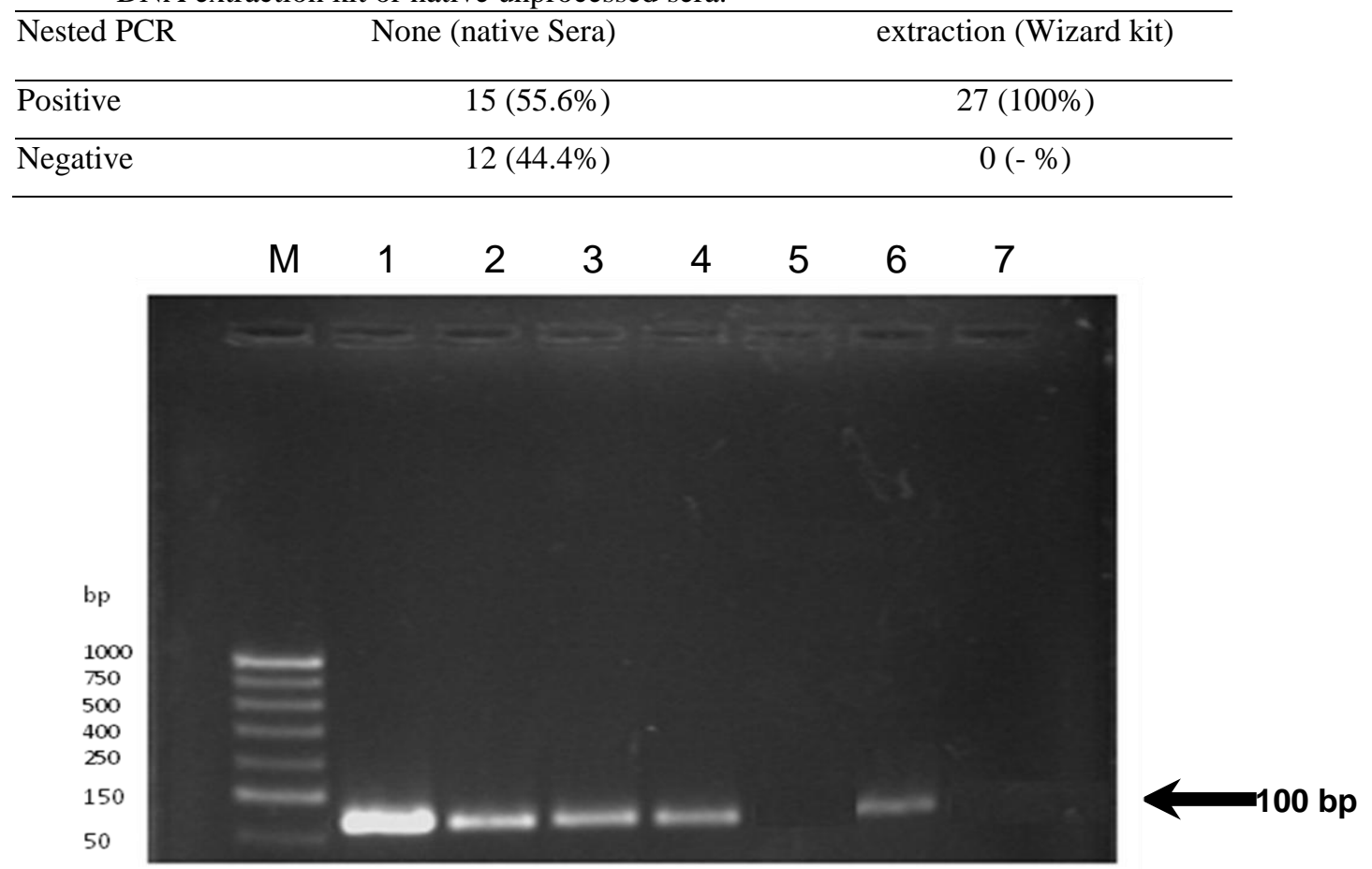

Fig. 3: Nested PCR results of HCMV DNA in serum samples Lanes 1, 2, 3, 4, 6 were positive for HCMV DNA, Lanes 5, 7 were negtive for HCMV DNA. M= DNA marker 


\section{DISCUSSION}

HCMV is detected earlier by PCR than by other techniques (Gerna et al., 1991). The uniplex PCR for HCMV DNA detection followed by confirmatory nested-PCR with $\mathrm{gB}$ primers has been used for processing urine, serum, plasma, saliva, milk and other secretion samples, showing high sensitivity and specificity. These sensitivity and specificity rates are higher than those reported for HCMV serological tests (Yamamoto et al., 2001).

There is an urgent need for technical standardization of procedures used for isolation and amplification of DNA. It seemed that the influence of methodological aspects such as DNA extraction procedures are important for the sensitivity and specificity of HCMV DNA detection from cell free sera by PCR (Klaus et al., 1997).

Several techniques, using different clinical samples have been employed to detect HCMV-DNA either by boiling serum samples without DNA extraction (Spector et al., 1992, Aspin et al., 199 1994, Freyuthet al., 1994) or by using recently DNA commercial kits (Bayram et al., 2009). Two decade ago, Ishigakiet al., (1991) demonstrated that the detection of HCMV-DNA in serum or plasma samples without any performance extraction of DNA has a disadvantage regarding the lower sensitivity of applied technique.

In this study, the percentage of positive nested-PCR of HCMV DNA extracted from serum samples were higher than that of positive cases for HCMV DNA without DNA extraction, indicating that the sensitivity of HCMV DNA amplification from DNA extracted serum was higher than that of amplification from native sera samples. The false negative nested-PCR $(44.4 \%)$ has been shown with the native serum sample. Whereas, no negative results was shown with the extracted HCMV-DNA with Wizard ${ }^{\circledR}$ DNA purification mini kit. It is possible that serum components acted as non-specific, non-enzymatic PCR inhibitors which were not eliminated by the thermal inactivation, but were eliminated after Wizard extraction (Evans et al., 1999).

It was reported that, the hemolytic serum of $\mathrm{HCV}$ patients contains a number of PCR inhibitors, one of which is hemin. Hemin, the prosthetic group of hemoglobin, reversibly binds to $\mathrm{Taq}$ polymerase and is a potent inhibitor of the enzyme (Byrnes et al., 1975). Such hemin is released from erythrocytes following hemolysis and is frequently associated with the withdrawing of blood. In addition, hemin inhibits viral reverse transcriptase activity in HIVinfected patients (Levere et al., 1991 and Klein et al., 1997).

Since the sensitivity of PCR for the amplification of HCMV DNA sequences in serum may often be reduced due to the presence of inhibitory factors. Still the method of DNA extraction has perfect effect to detect the target nucleic acid in clinical diagnostic samples (Klein et al., 1997).

Interestingly, the number of samples with positive HCMV-DNA amplification in cases of DNA extracted sera of $\mathrm{HCV}$ patients was higher than that from native sera of the same patients. This may be attributed to the effect of Wizard ${ }^{\circledR}$ DNA purification mini kit in decreasing the effect of inhibitors on detection of HCMV DNA in sera of HCV patients. Similar results were reported by Gerna et al., (1994), Zipeto et al., (1995), Klaus et al., (1997) and Klein et al., (1997).

\section{CONCLUSION}

This study concluded that, detection of HCMV DNA by nested PCR from native sera without DNA extraction was less sensitive than that by using DNA extraction kit. DNA extraction and 
purification methods had significant influence on the quality of DNA. DNA purification kits improved the accuracy of nested PCR results in clinical samples.

\section{REFERENCES}

Abdolreza, S.; Mahin, J.; Mohammad, R.; Abdolhosin, M.; Malihe, A.; Tasnim, E.; and Sima, H. (2010): Cytomegalovirus Immunity in Pregnancy in South of Iran. American Journal of Infectious Diseases 6 (1): 8-12.

Aquino, V.H. and Figueiredo1, L.T.M. (2001): Cytomegalovirus infection in renal transplant recipients diagnosed by nested-PCR, Brazilian Journal of Medical and Biological Research, 34: 93-101.

Aspin, M.M., Gallez-Hawkins, G.M., Giugni, T.D., Tegtmeier, B., Lang, D.J., Schmidt, G.M., Forman, S., Zaia, A.J., (1994): Comparison of plasma PCR and bronchoalveolar lavage fluid culture for detection of cytomegalovirus infection in adult bone marrow transplant recipients. J. Clin. Microbiol. 32, 2266-2269

Bayram, A., ozkur, A., Erkilic, S. (2009): Prevalence of human cytomegalovirus co-infection in patients with chronic viral hepatitis $\mathrm{B}$ and $\mathrm{C}$ : A comparison of clinical and histological aspects. Journal of Clinical Virology 45; 212-217.

Bevan, I.S., Daw, R.A., Day, P. J., Ala, F. A. \& Walker, M. R. (1991). Polymerase chain reaction for detection of human cytomegalovirus infection in a blood donor population. British Journal of Haematology 78, 9499.

Brytting, M., Xu, W., Wahren, B., Sundqvist, V.A., (1992): Cytomegalovirus DNA detection in sera from patients with active cytomegalovirus infections. J. Clin. Microbiol. 30, 1937-1941.

Byrnes, J. J., K. M. Downey, L. Esserman, and A. G. So. (1975): Mechanism of hemin inhibition of erythroid cytoplasmatic DNA polymerase. Biochemistry 14:796-799.

Caliendo, AM.; St George, K.; Kao, SY.; Allega, J.; Tan, BH.; Lafontaine, R.; Bui, L. and Rinaldo, CR. (2000). Comparison of quantitative cytomegalovirus (CMV) PCR in plasma and CMV antigenemia assay: clinical utility of the prototype Amplicor CMV Monitor test in transplant recipients. J Clin Microbiol; 38: 2122-7.

Evanse, P. C.; Gray, J.J.; Wreghitt, T. G.; Marcusf, R. E. and Alexander, G. J. M. (1999): Comparison of three PCR techniques for detecting cytomegalovirus (CMV) DNA in serum, detection of early antigen fluorescent foci and culture for the diagnosis of CMV infection. J. Med. Microbiol. Vol. 48; 10291035.

Freymuth, F., Gennetay, E., Petitjean, J., Eugene, G., Hurault De Ligny, B., Ryckelynck, J.P., Legoff, C., Hazera, P., Bazin, C., (1994): Comparison of nested PCR for detection of DNA in plasma with pp65 leukocytic antigenemia procedure for diagnosis of human cytomegalovirus infection. J. Clin. Microbiol. 32, 1614-1618.

Gerna, G., Zipeto, D., Parea, M., Revello, M.G., Silini, E., Percivalle, E., Zavattoni, M., Grossi, P., Milanesi, G., (1991): Monitoring of human cytomegalovirus infections and ganciclovir treatment in heart transplant recipients by determination of viremia, antigenemia, and DNAemia. J. Infect. Dis. 164, 488-498. 
Gerna, G., Furione, M., Baldanti, F., Sarasini, A., (1994): Comparative quantitation of human cytomegalovirus DNA in blood leukocytes and plasma of transplant and AIDS patients. J. Clin. Microbiol. 32, 2709-2717.

Gleaves, C.A., Smith, T.F., Shuster, E.A., Pearson, G.R., (1984): Rapid detection of cytomegalovirus in MRC-5 cells inoculated with urine specimens by using low-speed centrifugation and monoclonal antibody to an early antigen. J. Clin. Microbiol. 19, 917-919.

Hamprecht, K., Gerth, H.J., 1994. Detection of human cytomegalovirus (HCMV)-DNA from granulocytes and peripheral blood mononuclear cells (PBMC) of immunosuppressed patients by nested PCR: Lack of correlation to isolation of infectious virus. In: Rolfs, A., Weber-Rolfs, I., Finckh, U., (Eds.), Methods in DNA Amplification. Plenum Press, New York, pp. 145-153.

Ishigaki, S., Takeda, M., Kura, T., Ban, N., Saitoh, T., (1991): Cytomegalovirus DNA in the sera of patients with cytomegalovirus pneumonia. Br. J. Haematol. 79, 198- 204.

Jones, R.; Lynne, N.; Beattie, B.; Westmoreland, D.; and Fox, J. (2000): Development and Application of a PCR-Based Method Including an Internal Control for Diagnosis of Congenital Cytomegalovirus Infection $. J . \quad$ Clinical microbiology; 38:1: 1-6.

Klaus, H., Elfriede, M., Gerhard, J., (1997): Semi-quantitative detection of cytomegalovirus DNA from native serum and plasma by nested PCR: influence of DNA extraction procedures,
Journal of Virological Methods 69; 125-135.

Klein, A.; Barsuk, R.; Dagan, S.; Nusbaum, O.; Shouval, D.; and Galun, E. (1997): Comparison of Methods for Extraction of Nucleic Acid from Hemolytic Serum for PCR Amplification of Hepatitis B Virus DNA Sequences. Journal of Clinical Microbiology, 35; 1897-1899.

Levere, R. D., Y.-F. Gong, A. Kappas, D.

J. Bucher, G. P. Wormser, and N. G. braham. (1991): Heme inhibits human immunodeficiency virus 1 replication in cell culture and enhances the antiviral effect of zidovudine. Proc. Natl. Acad. Sci. USA 88:1756-1759.

Liliane G.K., and Denis, C. (2001): Diagnosis and prognostic markers of HCMV infection, Journal of Clinical Virology, 21; 213-221

Nelson, C. T., and G. J. Demmler. (1997): Cytomegalovirus infection in the pregnant mother, fetus and newborn infant. Clin. Perinatol. 24:151-160.

Patel, R., Smith, T.F., Espy, M., Wiesner, R.H., Krom, R.A.F., Portela, D., Paya, C.V., (1994): Detection of cytomegalovirus DNA in sera of liver transplant recipients. J. Clin. Microbiol. 32, 1431-1434.

Rogers, B. B., Alpert, L. C., Hine, E. A. \& Buffone, G. J. (1990). Analysis of DNA in fresh and fixed tissue by the polymerase chain reaction. American Journal of Pathology 136, 541-548.

Spector, S.A.; Merrill, R.; Wolf, D. and Dankner, W.M. (1992): Detection of human cytomegalovirus in plasma of AIDS patients during acute visceral disease by DNA amplification. J. Clin. Microbiol. 30: 2359-2365.

The, TH.; Van den Berg, AP.; Harmsen, MC.; Van der Beij, W.; and Van Son, WJ., (1995). The 
cytomegalovirus antigenemia assay: a plea for standardization. Scand J Infect Dis Suppl; 99: 25-9

Weber, B., Nestler, U., Ernst, W., Rabenau, H., Braner, J., Birkenbach, A., Scheuermann, E.H., Schoeppe, W., Doerr, H.W., (1994): Low correlation of human cytomegalovirus

DNA amplification by polymerase chain reaction with cytomegalovirus disease in organ transplant recipients. J. Med. Virol. 43, 187193.

Yamamoto, AY, Pinhata MMM, Pinto PCG, Figueiredo LTM, Jorge, S.
(2001):

Congenital cytomegalovirus infection in preterm and full-term newborn infants from a population with a high seroprevalence rate. The Pediatric Infectious Diseases Journal 20: 188-192.

Zipeto, D., Morris, S., Hong, C., Dowling, A., Wolitz, R., Merigan, T.C., Rasmussen, L., (1995): Human cytomegalovirus (CMV) DNA in plasma reflects quantity of CMV DNA present in leukocytes. J. Clin. Microbiol. 33, 2607-2611.

\section{ARABIC SUMMARY}

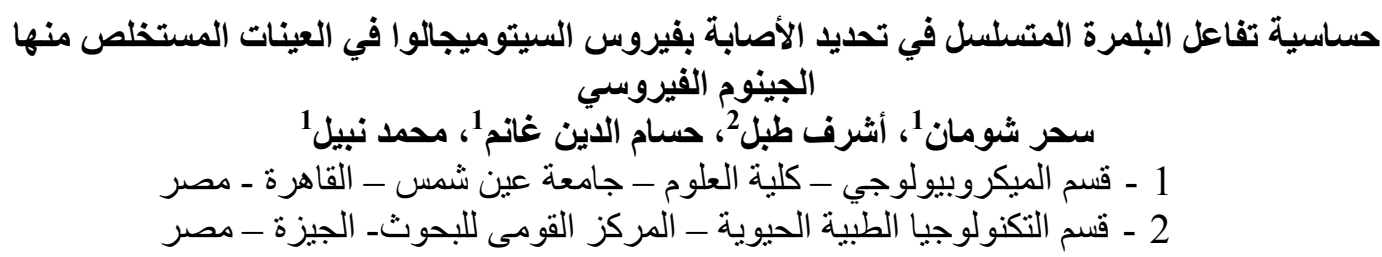

يستخدم تفاعل البلمرة المتسلسل (PCR) عادة في تشخيص الأمر اض الفيروسية نظراء لحساسيته و

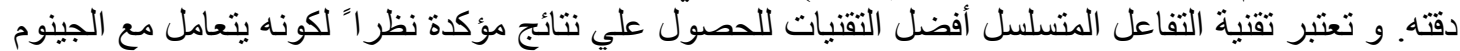

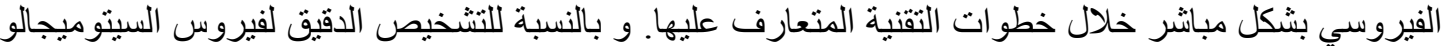

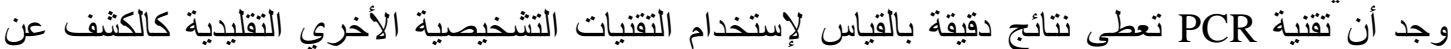

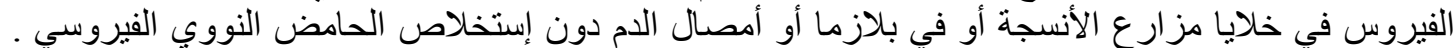

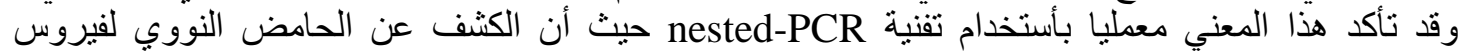

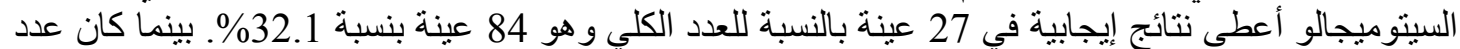

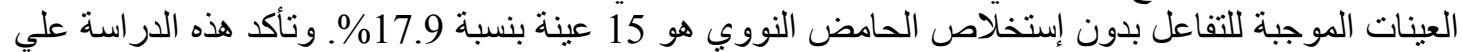

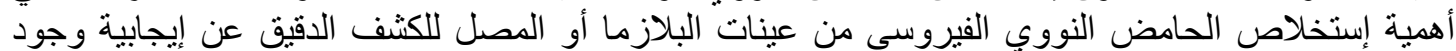

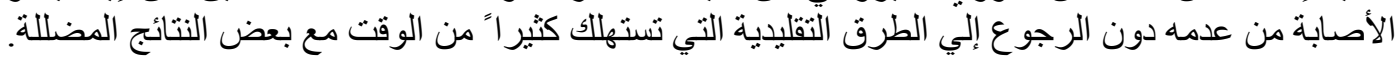

